\title{
Pengaruh Komitmen Organisasi Dan Implementasi Budaya Organisasi Terhadap Kinerja Karyawan Bank Syariah Lantabur
}

\author{
Murni Rahmawati, Kristin Juwita \\ STIE PGRI Dewantara Jombang
}

\author{
Korespondensi: kristinjuwita66@gmail.com
}

\begin{abstract}
Abstrak
Penelitian ini bertujuan untuk mengetahui pengaruh komitmen organisasi dan implementasi budaya organisasi terhadap kinerja karyawan PT. BPRS Lantabur. Jenis penelitian ini adalah verifikatif dengan menggunakan pendekatan kuantitatif. Populasi dalam penelitian ini adalah seluruh karyawan bagian funding dan lending PT. BPRS Lantabur dengan sampel yang berjumlah 30 orang dan menggunakan teknik sampel jenuh. Pengumpulan data menggunakan angket sedangkan analisis data dilakukan dengan menggunakan analisis linear regresi berganda. Berdasarkan hasil penelitian menunjukkan bahwa komitmen organisasi yang tinggi mampu meningkatkan kinerja karyawan PT. BPRS Lantabur dan implementasi budaya organisasi yang baik mampu meningkatkan kinerja karyawan PT. BPRS Lantabur.
\end{abstract}

Kata kunci: Komitmen Organisasi, Implementasi Budaya Organisasi, Kinerja Karyawan.

\begin{abstract}
This study aims to determine the effect of organizational commitment and implementation of organizational culture on the performance of employees of PT. BPRS Lantabur. This type of research is verification using a quantitative approach. The population in this study were all employees of the funding and landing section of PT. BPRS Lantabur with a sample of 30 people and using a saturated sample technique. Data collection uses questionnaires while data analysis is done using linear multiple regression analysis. The results of this study is high organizational commitment can improve the performance of employees of PT. BPRS Lantabur and the implementation of a good organizational culture can improve the performance of employees of PT. BPRS Lantabur.
\end{abstract}

Keywords: Organizational Commitment, Organizational Culture Implementation, Employee Performance.

\section{A. PENDAHULUAN}

Sumber daya manusia merupakan faktor penting dalam suatu organisasi. Apapun bentuk serta tujuan organisasi tidak lepas dari karyawan karena kinerja karyawan berdampak pada peningkatan kinerja organisasi. Kinerja adalah hasil atau tingkat keberhasilan seseorang secara keseluruhan selama periode tertentu di dalam melaksanakan tugas di bandingkan dengan berbagai kemungkinan, seperti standar hasil kerja, target atau sasaran atau kriteria yang telah di tentukan terlebih dahulu dan telah di sepakati bersama.

Komitmen karyawan merupakan salah satu kunci yang turut menentukan berhasil tidaknya suatu organisasi untuk mencapai tujuannnya (Bey, M. T., \& Dewi, R. C. K, 2018). Mathis dan Jackson dalam Sasono (2004) mendefinisikan Komitmen Organisasional sebagai derajat dimana karyawan percaya dan mau menerima tujuan - tujuan organisasi dan akan tetap tinggal atau tidak akan meninggalkan organisasinya. Karyawan yang mempunyai komitmen pada organisasi cenderung menunjukkan sikap kerja yang penuh perhatian terhadap tugasnya, mereka bertanggung jawab untuk menyelesaikan tugas - tugas serta loyal terhadap perusahaan. Menurut hasil penelitian yang dilakukan Ferryansyah (2013) menyatakan bahwa komitmen organisasi berpengaruh secara signifikan terhadap kinerja karyawan, tetapi menurut penelitian yang di lakukan oleh Marsoit et al (2017) menunjukkan bahwa komitmen organisasi tidak berpengaruh terhadap kinerja karyawan. Selain itu menurut hasil penelitian yang dilakukan oleh Mekta (2017) menyatakan bahwa komitmen organisasi justru berpengaruh negatif terhadap kinerja karyawan. 
Faktor lain yang dapat mempengaruhi kinerja karyawan selain komitmen organisasi adalah budaya organisasi. Menurut Robbins (2006), Budaya organisasi merupakan sistem nilai bersama dalam suatu organisasi yang menentukan tingkatan bagaimana para karyawan melakukan kegiatan untuk mencapai tujuan organisasi. Penerapan budaya organisasi yang baik akan memperlancar kinerja karyawan. Oleh sebab itu, budaya organisasi sangat penting, karena merupakan kebiasaan - kebiasaan yang ada dalam organisasi. Pada hakikatnya semua organisasi memiliki budaya, namun tidak semua budaya organisasi sama kuatnya dalam mempengaruhi perilaku dan tindakan para karyawan. Dalam hal ini jelaslah bahwa budaya yang tertanam dan dilaksanakan dalam organisasi memiliki kontribusi yang signifikan terhadap kinerja karyawan. Menurut Pratiwi (2012) dalam penelitiannya menjelaskan bahwa budaya organisasi mempunyai pengaruh yang signifikan terhadap kinerja karyawan, akan tetapi penelitian yang dilakukan oleh Maabuat (2016) menyatakan bahwa budaya organisasi tidak berpengaruh terhadap kinerja. Selain itu dalam penelitian Sriekaningsih (2017) menunjukkan bahwa budaya organisasi berpengaruh negatif terhadap kinerja karyawan. Ketika karyawan memahami nilai - nilai yang ada dalam organisasi, maka akan mempengaruhi cara bekerja bekerja karyawan tersebut.

PT Bank Perkreditan Rakyat Syariah (BPRS) Lantabur merupakan perusahaan yang bergerak dalam bidang keuangan yang telah berdiri selama 12 tahun .Fenomena yang terjadi dalam perusahaan ini yaitu kinerja dari karyawan bagian funding (penghimpunan dana) dan lending (penyaluran dana) yang bekerja di kantor tersebut sudah bagus, hal tersebut dapat di lihat dari kualitas kerja karyawan PT BPRS Lantabur bagian funding dan lending mampu bekerja semaksimal mungkin demi kemajuan perusahaan. Karyawan mampu bekerja sesuai dengan standar yang di tentukan oleh perusahaan seperti bersikap ramah dan sopan terhadap nasabah serta pelayanan yang memuaskan. Pada tahun 2012 - 2017, secara berturut - turut bagian keuangan mendapat penghargaan sebagai kinerja keuangan terbaik dalam level BPR dari info bank (redaksi@infobanknews.com). Hal ini tidak lepas dari peran karyawan funding dan lending atas kinerjanya. Penghargaan tersebut tentunya memacu karyawan untuk bekerja lebih baik.

Kinerja karyawan yang baik tidak lepas dari implementasi budaya organisasi dan tingginya komitmen kerja karyawan terhadap organisasi. Budaya Organisasi di PT BPRS Lantabur berjalan dengan baik, seperti yang tercermin pada perusahaan tersebut yaitu sebelum melakukan pekerjaan masing - masing, setiap pagi perusahaan menerapkan evaluasi kinerja dan doa bersama seluruh karyawan. Selain itu pada setiap hari jum'at legi karyawan PT BPRS Lantabur Tebuireng melakukan khataman qur'an ( Waqi'ah ) dan mengadakan pengajian dengan mengundang salah satu ulama untuk menjadi penceramah. Sikap fleksibel dan familiar karyawan terhadap nasabah serta kedekatan mereka terhadap semua kalangan nasabah membuat mereka disenangi oleh banyak orang. Perusahaan juga menerapkan budaya sholat secara berjamaah di mushola, dalam hal ini pimpinan dan karyawan bergantian mengimami sholat.

Komitmen kerja karyawan dalam bekerja sangat tinggi. Berdasarkan hasil wawancara dengan beberapa karyawan funding dan lending, sebagian besar karyawan sudah merasa nyaman dalam bekerja dan tidak berkeinginan untuk bekerja di tempat lain, mereka beranggapan bahwa perusahaan tersebut sangat membantu kehidupan para karyawan yang bekerja diperusahaan tersebut.

Dari uraian yang telah disampaikan, maka rumusn masalah yang diangkat pada penelitian ini adalah: 1) Apakah komitmen organusasi berpengaruh terhadap kinerja karyawan? Dan 2) Apakah implementasi budaya organisasi berpengaruh terhadap kinerja karyawan PT. BPRS Lantabur?. Diharapkan, dari hasil penelitian ini berguna sebagai bahan 
masukan bagi pihak manajemen khususnya dan pihak lain yang tertarik kajian tentang budaya organisasi, komitmen organisasi dan kinerja karyawan.

\section{B. TINJAUAN PUSTAKA \\ 1. Komitmen Organisasi}

Menurut Robbins dan Judge (2007), Komitmen organisasi merupakan suatu keadaan dimana seseorang memihak organisasi serta tujuan - tujuan dan keinginan nya untuk mempertahankan keanggotaannya dalam organisasi. Sedangkan Mathias dan Jackson (2009) mendefinisikan komitmen organisasional sebagai derajat dimana karyawan percaya dannmau menerima tujuan - tujuan organisasi dan akan tetap tinggal atau tidak akan meninggalkan organisasinya. Allen dan Meyer (1997) menyatakan bahwa komitmen organisasional merupakan identifikasi pegawai terhadap persetujuan untuk mencapai misi unit atau misi perusahaan. Jadi dapat di jelaskan bahwa Komitmen organisasi ialah sikap kesediaan diri seseorang untuk sepenuhnya membantu perusahaan mencapai tujuan.

Meyer, Allen (1997) mengemukakan ada tiga komponen tentang komitmen organisasi baik itu melibatkan karyawan maupun pimpinan yaitu :

a. Affective commitment ( Komitmen Afektif ), terjadi apabila karyawan ingin menjadi bagian dari organisasi karena adanya ikatan emosional.

Berikut merupakan indikator komitmen afektif :

1. Keinginan berkarir di organisasi.

2. Rasa percaya terhadap organisasi.

3. Pengabdian kepada organisasi.

b. Continuance commitment ( Komitmen Berkelanjutan ) muncul apabila karyawan tetap bertahan pada suatu organisasi karena membutuhkan gaji dan keuntungan - keuntungan lain, atau karena karyawan tersebut tidak menemukan pekerjaan lain. Komitmen berkelanjutan di bagi menjadi beberapa indikator, yaitu :

1. Kecintaan pegawai kepada organisasi.

2. Keinginan bertahan dengan pekerjaannya.

3. Bersedia mengorbankan kepentingan pribadi.

4. Keterikatan pegawai kepada pekerjaan.

5. Tidak nyaman meninggalkan pekerjaan saat ini.

c. Normative commitment (Komitmen Normatif ), timbul dari nilai - nilai dalam diri karyawan. Karyawan bertahap menjadi anggota organisasi karena adanya kesadaran bahwa komitmen terhadap organisasi merupakan hal yang seharusnya dilakukan. Berikut merupakan indikator dari komitmen normatif :

1. Kesetiaan terhadap organisasi.

2. Kebahagiaan dalam bekerja.

3. Kebanggaan bekerja pada organisasi.

\section{Implementasi Budaya Organisasi}

Robbins (2006) menyatakan bahwa budaya organisasi merupakan system nilai bersama dalam suatu organisasi yang menentukan tingkatan bagaimana para karyawan melakukan kegiatan untuk mencapai tujuan organisasi. Wirawan (2007) berpendapat Budaya Organisasi merupakan norma, nilai - nilai, asumsi, kepercayaan, filsafat, kebiasaan organisasi dan sebagainya yang di kembangkan dalam waktu yang lama oleh pendiri, pemimpin, dan anggota organisasi yang disosialisasikan dan diajarkan kepada anggota baru serta diterapkan dalam aktivitas organisasi sehingga pengaruh pola pikir, sikap, dan perilaku anggota organisasi dalam melayani konsumen dan mencapai tujuan organisasi.

Kreitner dan Kinicki (2005), menyatakan bahwa budaya organisasi merupakan nilai dan keyakinan bersama yang mendasari identitas organisasi yang berfungsi sebagai pemberi rasa

JMD: Jurnal Riset Manajemen Dan Bisnis Dewantara

Vol 2 No 2, Juli 2019

ejournal.stiedewantara.ac.id/index.php/JMD 
identitas kepada anggota, mempromosikan komitmen, kolektif, meningkatkan stabilitas sistem sosial, dan pengendalian perilaku para organisasi. Berdasarkan beberapa definisi di atas maka dapat di jelaskan budaya organisasi merupakan suatu nilai yang di yakini oleh seluruh anggota dan dijadikan pedoman untuk melakukan kegiatan dalam organisasi. Budaya organisasi menurut PT BPRS Lantabur yaitu sebagai berikut :

1. Menjalankan nilai - nilai budaya yang berlandaskan syariah Islam.

2. Fleksibel dan familiar karyawan terhadap nasabah. Hal tersebut dapat di artikan sebagai sikap seseorang yang luwes atau mudah menyesuaikan diri terhadap lingkungan sekitar serta mudah akrab dengan seseorang.

3. Evaluasi kinerja karyawan. Di gunakan untuk menjamin pencapaian sasaran dan tujuan perusahaan dan juga untuk mengetahui posisi perusahaan dan tingkat pencapaian sasaran perusahaan, terutama untuk mengetahui bila terjadi keterlambatan atau penyimpangan supaya segera di perbaiki, sehingga sasaran atau tujuan tercapai.

\section{Kinerja Karyawan}

Pabundu (2010) menyatakan bahwa kinerja adalah hasil - hasil fungsi pekerjaan / kegiatan seseorang atau kelompok dalam suatu organisasi yang dipengaruhi oleh berbagai faktor untuk mencapai tujuan organisasi dalam periode waktu tertentu. Hasibuan (2010) mengemukakan kinerja adalah suatu hasil kerja yang dicapai seseorang dalam melaksanakan tugas - tugas yang dibebankan kepadanya yang di dasarkan atas kecakapan, pengalaman, dan kesungguhan serta waktu. Sedangkan menurut Edison (2016), Kinerja adalah hasil dari suatu proses yang mengacu dan diukur selama periode waktu tertentu berdasarkan ketentuan atau kesepakatan yang telah di tetapkan sebelumnya. Kinerja merupakan hasil kerja karyawan secara kualitas dan kuantitas yang di capai dalam melaksanakan tugasnya sesuai dengan tanggung jawab yang di berikan kepadanya. Berdasarkan beberapa definisi diatas, maka dapat dijelaskan kinerja adalah hasil kerja individu atau tim dalam menyelesaikan tugas sesuai dengan tanggung jawabnya.

Mangkunegara (2006) menyatakan bahwa kinerja karyawan dapat diukur dengan:

1. Kualitas kerja, yaitu kerapian, ketelitian, dan keterkaitan hasil kerja dengan tidak mengabaikan volume pekerjaan. Dengan adanya kualitas kerja yang baik dapat menghindari tingkat kesalahan dalam penyelesaian suatu pekerjaan serta produktivitas kerja yang dihasilkan dapat bermanfaat bagi kemajuan perusahaan.

2. Kuantitas kerja, yaitu volume kerja yang dihasilkan dibawah kondisi normal. Kuantitas kerja menunjukkan banyaknya jenis pekerjaan yang dilakukan dalam satu waktu sehingga efisiensi dan efektivitas dapat terlaksana sesuai dengan tujuan perusahaan.

3. Tanggung jawab, yaitu menunjukkan seberapa besar karyawan dapat mempertanggung jawabkan hasil kerjanya, sarana dan prasarana yang dipergunakan serta perilaku kerjanya.

4. Inisiatif, yaitu menunjukkan seberapa besar kemampuan karyawan untuk menganalisis, menilai, menciptakan dan membuat keputusan terhadap penyelesaian masalah yang dihadapi.

5. Kerja sama, yaitu merupakan kesediaan karyawan untuk berpartisipasi dan bekerja sama dengan karyawan lain secara vertical atau horizontal didalam maupun luar pekerjaan sehingga hasil pekerjaan semakin baik.

\section{Kerangka Konseptual}

Berdasarkan latar belakang dan kajian pustaka maka dapat digambarkan rumusan hipotesis sebagai berikut: 


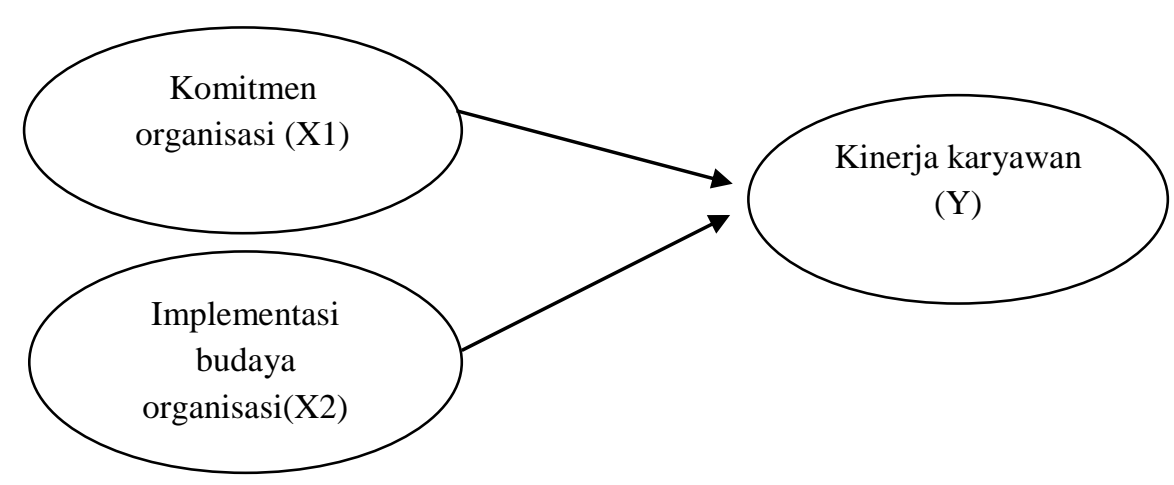

\section{Hipotesis}

\section{Gambar 1 Kerangka Konseptual}

H1 : Diduga Komitmen Organisasi berpengaruh positif dan signifikan terhadap kinerja karyawan.

H2 : Diduga Implementasi Budaya Organisasi berpengaruh positif dan signifikan terhadap kinerja karyawan.

\section{Metode Penelitian}

Penelitian ini menggunakan jenis penelitian verifikatif yaitu penelitian yang bertujuan untuk menguji kebenaran melalui pengumpulan data dilapangan (Arikunto, 2006). Dengan menggunakan pendekatan kuantitatif yaitu metode penelitian yang berlangsung pada filsafat positivisme bisa digunakan untuk meneliti pada populasi atau sampel tertentu, pengumpulan data menggunakan instrument penelitian, analisis data bersifat kuantitatif/statistik, dengan tujuan untuk menguji hipotesis yang telah ditetapkan. Skala pengukuran menggunakan skala Likert, Metode yang dipakai dalam penelitian ini adalah metode survei, yaitu responden diminta mengisi beberapa pernyataan dalam bentuk angket. Sedangkan sampel yang diambil adalah karyawan Bank Syariah PT.BPRS Lantabur bagian funding dan lending yang berjumlah 30 orang karyawan.

Penelitian ini menggunakan uji instrumen yaitu uji validitas dan uji reliabilitas, uji asumsi klasik. Serta menggunakan uji hipotesis yaitu uji $t$ dan koefisien determinasi $\left(\mathrm{R}^{2}\right)$ dengan bantuan program SPSS 24.

\section{HASIL PENELITIAN DAN PEMBAHASAN}

\section{Uji Validitas dan Reliabilitas}

Uji Validitas digunakan untuk mengukur sah atau valid tidaknya suatu kuesioner. Menurut Ghozali (2013) suatu kuesioner dapat dikatakan valid jika pertanyaan pada kuesioner mampu untuk mengungkapkan sesuatu yang diukur oleh kuesioner tersebut. Uji validitas pada penelitian ini menggunakan rumus Pearson Product Moment. Perhitungan uji validitas tersebut menggunakan bantuan SPSS 16. Bila hasil uji kemaknaan untuk $r$ menunjukkan r-hitung >0,3 dinyatakan valid (Sugiyono, 2007). Hasil dari pengolahan data primer tampak seperti tabel berikut:

Tabel 1: Hasil Pengujian Validitas

\begin{tabular}{|c|c|c|c|c|}
\hline $\begin{array}{c}\text { No } \\
\text { Item }\end{array}$ & Variabel & r hitung & r kritis & keterangan \\
\hline 1 & & 0,779 & 0,30 & Valid \\
\hline 2 & & 0,733 & 0,30 & Valid \\
\hline 3 & Komitmen & 0,841 & 0,30 & Valid \\
\hline
\end{tabular}

JMD: Jurnal Riset Manajemen Dan Bisnis Dewantara

Vol 2 No 2, Juli 2019

ejournal.stiedewantara.ac.id/index.php/JMD 


\begin{tabular}{|c|c|c|c|c|}
\hline 4 & \multirow{6}{*}{$\begin{array}{l}\text { Organisasi ( } \\
\text { X1) }\end{array}$} & 0,789 & 0,30 & Valid \\
\hline 5 & & 0,769 & 0,30 & Valid \\
\hline 6 & & 0,828 & 0,30 & Valid \\
\hline 7 & & 0,847 & 0,30 & Valid \\
\hline 8 & & 0,753 & 0,30 & Valid \\
\hline 9 & & 0,771 & 0,30 & Valid \\
\hline 1 & \multirow{4}{*}{$\begin{array}{c}\text { Budaya } \\
\text { Organisasi (X2) }\end{array}$} & 0,772 & 0,30 & Valid \\
\hline 2 & & 0,818 & 0,30 & Valid \\
\hline 3 & & 0,914 & 0,30 & Valid \\
\hline 4 & & 0,735 & 0,30 & Valid \\
\hline 1 & \multirow{5}{*}{$\begin{array}{c}\text { Kinerja } \\
\text { Karyawan (Y) }\end{array}$} & 0,730 & 0,30 & Valid \\
\hline 2 & & 0,841 & 0,30 & Valid \\
\hline 3 & & 0,744 & 0,30 & Valid \\
\hline 4 & & 0,671 & 0,30 & Valid \\
\hline 5 & & 0,711 & 0,30 & Valid \\
\hline
\end{tabular}

\section{Sumber: Data Primer yang diolah, 2018}

Berdasarkan tabel diatas dapat diketahui bahwa semua variabel penelitian memiliki nilai korelasi lebih besar dari $r$ kritis sehingga semua item pernyataan penelitian yang digunakan dinyatakan valid dan dapat digunakan untuk penelitian selanjutnya.

Reliabilitas menunjukkan pada suatu instrument cukup dapat dipercaya untuk digunakan sebagai alat pengumpul data karena instrumen tersebut adalah sudah baik (Arikunto, 2006). Reliabilitas untuk masing - masing variabel diringkas pada tabel 2 (dua) berikut :

Tabel 2: Hasil Pengujian Reliabilitas

\begin{tabular}{lccc}
\hline \multicolumn{1}{c}{ Variabel } & Alpha & Koefisien $\alpha$ & Keterangan \\
\hline Komitmen Organisasi $(\mathrm{X} 1)$ & 0,922 & 0,60 & Reliabel \\
\hline Budaya Organisasi $(\mathrm{X} 2)$ & 0,822 & 0,60 & Reliabel \\
\hline Kinerja Karyawan $(\mathrm{Y})$ & 0,773 & 0,60 & Reliabel \\
\hline
\end{tabular}

Sumber: Data Primer yang diolah, 2018

Berdasarkan tabel diatas dapat diketahui bahwa semua variabel penelitian memiliki nilai koefisiensi alpha lebih besar dari 0,6 sehingga semua item dinyatakan reliabel dan dapat digunakan untuk penelitian selanjutnya.

\section{Analisis Regresi Berganda}

Analisis regresi berganda dilakukan untuk mengetahui variabel komitmen organisasi (X1) dan implementasi budaya organisasi (X2) terhadap kinerja karyawan (Y). Hasil regresi dapat dilihat pada tabel dibawah ini :

Tabel 3: Hasil Analisa Regresi Linear Berganda

\begin{tabular}{lcccccc}
\hline & \multicolumn{2}{c}{ Unstandardized Coefficients } & \multicolumn{2}{c}{ Standardized Coefficients } & & \\
\cline { 2 - 5 } Model & $\mathrm{B}$ & \multicolumn{1}{c}{ Std. Error } & & Beta & & \multicolumn{1}{c}{ Sig. } \\
\hline 1 (Constant) & 6.907 & 2.525 & & & 2.735 & .011 \\
\hline $\mathrm{X} 1$ & .182 & .058 & .434 & 3.112 & .004 \\
\hline $\mathrm{X} 2$ & .486 & .148 & .458 & 3.285 & .003 \\
\hline
\end{tabular}

Sumber : lampiran output SPSS, 2018

Berdasarkan hasil analisa regresi yang disajikan dalam tabel 3 (iga) tmaka didapatkan persamaan sebagai berikut : $\mathrm{Y}=6,907+0,182(\mathrm{X} 1)+0,486(\mathrm{X} 2)$ 
Persamaan regresi menunjukkan bahwa adanya komitmen organisasi dan implementasi budaya organisasi memiliki pengaruh positif terhadap kinerja karyawan, artinya semakin tinggi komitmen organisasi dan implementasi budaya organisasi, maka kinerja karyawan juga akan mengalami peningkatan, begitu juga sebaliknya.

\section{Pengujian Hipotesis Dengan Uji T}

Uji-T digunakan untuk menguji pengaruh variabel bebas secara parsial terhadap variabel terikat. Hasil nilai signifikan masing-masing variabel dapat dilihat pada tabel berikut ini :

Tabel 4: Hasil Uji-T

\begin{tabular}{llrrc}
\hline No. & Variabel & t hitung & Signifikan & Keterangan \\
\hline 1. & Komitmen organisasi (X1) & 3,112 & 0,004 & Signifikan \\
\hline 2. & Implementasi Budaya Organisasi (X2) & 3,285 & 0,003 & Signifikan \\
\hline
\end{tabular}

Sumber : Data primer yang diolah, 2018

Berdasarkan tabel 4 (empat) diatas maka dapat dijelaskan bahwa :

1. Pengujian hipotesis pertama $(\mathrm{H} 1)$

Variabel komitmen organisasi (X1) memiliki $\mathrm{t}$ hitung $=3,112$ dan signifikan sebesar 0,004 karena nilai $t_{\text {sig }}=0,004<\alpha=0,05$. Dengan demikian dapat dinyatakan bahwa komitmen organisasi berpengaruh terhadap kinerja karyawan. H1 diterima.

2. Pengujian hipotesis kedua $(\mathrm{H} 2)$

Variabel implementasi budaya organisasi (X2) memiliki thitung $=3,285$ dan signifikan sebesar 0,003 karena nilai $\mathrm{t}_{\text {sig }}=0,003>\alpha=0,05$. Dengan demikian dapat di nyatakan bahwa implementasi budaya organisasi berpengaruh terhadap kinerja kayawan. H2 diterima.

\section{Pengujian Koefisiensi Determinasi $\left(\mathbf{R}^{2}\right)$}

Untuk mengetahui besarnya pengaruh variabel bebas terhadap variabel terikat dapat dilihat dari besarnya nilai $\mathrm{R}$, sebagaimana yang tampak pada tabel berikut:

Tabel 5: Nilai determinasi $\left(\mathbf{R}^{2}\right)$

\begin{tabular}{llrrrrr}
\hline \multicolumn{6}{c}{ Model Summary $^{\mathbf{b}}$} \\
\hline Model & $\mathrm{R}$ & $\mathrm{R}$ Square & \multicolumn{2}{c}{ Adjusted R } & \multicolumn{2}{c}{ Std. Error of the } \\
\hline 1 & $.741^{\mathrm{a}}$ & .549 & .516 & 1.669 & 1.758 \\
\hline
\end{tabular}

a. Predictors: (Constant), X2, X1

b. Dependent Variable: Y

Sumber : lampiran output SPSS, 2018

Nilai Adjusted $R^{2}$ sebesar 0,516 artinya kinerja melalui penilaian ini dipengaruhi oleh variabel komitmen organisasi dan implementasi budaya organisasi sebesar 51,6 \%, dan sisanya dipengaruhi oleh faktor lain yang tidak diteliti dalam penelitian ini yaitu $100 \%$ $51,6 \%=48,4 \%$ seperti kepuasan kerja dan lingkungan kerja.

\section{Pengaruh Komitmen Organisasi terhadap Kinerja Karyawan.}

Berdasarkan hasil penelitian menunjukkan bahwa komitmen organisasi yang tinggi dapat meningkatkan kinerja karyawan funding dan lending. jadi jika semakin baik komitmen organisasi karyawan maka akan meningkatkan kinerja karyawan pada PT. BPRS Lantabur. Hal ini didukung jawaban responden yang menunjukkan bahwa komitmen tinggi.

Komitmen organisasi merupakan sikap kesediaan diri seseorang untuk sepenuhnya membantu perusahaan mencapai tujuan. Semakin tinggi keterlibatan karyawan dalam pekerjaan akan mendorong karyawan untuk memberikan kontribusi yang lebih baik. Hal tersebut dapat terlihat dari sikap ketersediaan karyawan funding dan lending untuk bersedia 
bekerja sampai masa pensiun di PT. BPRS Lantabur. Karyawan funding dan lending juga percaya terhadap operasional kerja seperti pekerjaan yang dilakukan oleh karyawan. Karyawan bersedia memberikan tenaga dan ide - ide untuk kemajuan PT. BPRS Lantabur. Selain itu karyawan bertahan untuk bekerja di PT. BPRS Lantabur tanpa berkeinginan untuk pindah ke tempat lain dan bersedia mengorbankan kepentingan pribadi demi kepentingan PT. BPRS Lantabur. Karyawan memiliki perasaan keterikatan terhadap pekerjaan dan setia bekerja di PT. BPRS Lantabur. Karyawan juga merasa senang untuk bekerja di PT. BPRS lantabur. Komitmen yang tinggi akan mampu mempengaruhi kinerja karyawan untuk bekerja lebih giat terlihat dari mampu bekerja sesuai standar dan mencapai target, karyawan mampu bekerjasama dengan baik. Hal ini sesuai dengan pendapat Putra (2015) yang menunjukkan bahwa komitmen organisasi berpengaruh positif dan signifikan terhadap kinerja karyawan serta penelitian yang dilakukan Mutiarni, R., \& Hidayati, N. (2018) yang menyatakan bahwa Pengaruh Kepuasan Kerja Dan Komitmen Organisasi Terhadap Organizational Citizenship Behavior (OCB)

\section{Pengaruh Implementasi Budaya Organisasi terhadap Kinerja Karyawan.}

Berdasarkan hasil penelitian menunjukkan bahwa implementasi budaya organisasi dapat meningkatkan kinerja karyawan funding dan lending pada PT. BPRS Lantabur. hal ini didukung dari jawaban responden yang menunjukkan bahwa implementasi budaya organisasi berjalan dengan baik seperti karyawan funding dan lending menjalankan nilai - nilai budaya yang sudah ditetapkan oleh oleh PT. BPRS Lantabur seperti waqi'ah, sholat berjama'ah. Karyawan funding dan lending juga mampu menyesuaikan diri terhadap lingkungan tempat mereka bekerja. Karyawan funding dan lending juga merasa akrab terhadap semua kalangan nasabah serta selalu melakukan evaluasi kinerja bersama - sama setiap pagi sebelum mereka melaksanakan pekerjaan masing - masing. Hal ini menunjukkan bahwasanya implementasi budaya organisasi yang baik maka kinerja karyawan juga akan semakin tinggi, terlihat dari karyawan mampu bekerja sesuai standar serta mampu mencapai target kerja yang di tetapkan oleh perusahaan, karyawan juga mampu bekerjasama dengan baik.

Implementasi budaya organisasi merupakan suatu nilai yang diyakini oleh seluruh anggota dan dijadikan pedoman untuk melakukan kegiatan dalam organisasi. Hasil penelitian yang mendukung penelitian ini adalah Sutrisno (2017) yang menjelaskan bahwa implementasi budaya organisasi berpengaruh positif dan signifikan terhadap kinerja karyawan.

\section{E. PENUTUP}

Berdasarkan hasil penelitian dan pembahasan yang telah disampaikan, maka dapat disimpulkan bahwa Komitmen organisasi serta Implementasi yang tinggi dapat meningkatkan kinerja karyawan funding dan lending pada PT. BPRS Lantabur. Hasil penelitian ini juga menunjukkan bahwa hipotesis yang diajukan pada awal penelitian telah terbukti.

Dari hasil penelitan tersebut, disarankan kepada pihak manajemen PT. BPRS Lantabur untuk memperhatikan sikap karyawan. Perusahaan tidak harus melakukan perubahan besar dalam menyikapi karyawan, hanya saja karyawan perlu mempertahankan niatnya bersedia bekerja sampai masa pensiun di PT. BPRS Lantabur serta meningkatkan kepercayaan tentang operasional kerja dalam perusahaan tersebut. Selain itu karyawan funding dan lending juga lebih meningkatkan kesediaan mereka untuk memberikan tenaga dan ide - ide demi kemajuan PT. BPRS Lantabur. Karyawan funding dan lending sebaiknya bertahan bekerja di perusahaan tersebut guna mencapai tujuan perusahaan serta perlu mengutamakan pekerjaan terlebih dahulu dibanding kepentingan pribadi, apabila kepentingan tersebut dirasa kurang begitu penting bagi karyawan maka di sarankan untuk lebih mendahulukan pekerjaan karyawan tersebut. Selain itu, karyawan funding dan lending perlu 
mempertahankan niatnya untuk setia bekerja pada PT. BPRS Lantabur. Karyawan funding dan lending juga perlu meningkatkan keterikatan mereka terhadap pekerjaan dengan lebih bersemangat lagi dalam bekerja untuk tercapainya tujuan dan keberhasilan PT. BPRS Lantabur serta meningkatkan kesenangan mereka dalam bekerja di lapangan.

Karyawan juga perlu meningkatkan lagi inisiatif terhadap permasalahan yang terjadi dalam pekerjaan, sehingga masalah yang dihadapi cepat terselesaikan serta mempertahankan hasil pencapaian target yang sudah melebihi batas target yang ditentukan oleh PT. BPRS Lantabur. Karyawan juga perlu meningkatkan tanggung jawab atas hasil dari pekerjaan yang di lakukan di PT. BPRS Lantabur serta bekerjasama dengan tim kerja masing - masing untuk mencapai tujuan perusahaan.

Bagi peneliti selanjutnya yang hendak melakukan penelitian sejenis disarankan untuk mempertimbangkan variabel - variabel lainnya yang berpengaruh terhadap kinerja karyawan seperti kompensasi, kepuasan, motivasi serta kompetensi, sehingga kinerja karyawan yang diharapkan dapat mencapai titik optimal.

\section{DAFTAR PUSTAKA}

Allen, N. J. \& J. P. Meyer. ( 1997 ). Commitment in The Workplace Theory Research And Application. California : Sage Publications.

Arikunto, Suharsimi . (2006). Prosedur Penelitian Suatu Pendekatan Praktik ( Edisi Revisi VI ). Jakarta : PT Asdi Mahasatya,

Bey, M. T., \& Dewi, R. C. K. (2018). Pengaruh Budaya Organisasi Dan Komitmen Organisasi Terhadap Kinerja Karyawan Pada BPJS Ketenagakerjaan Kantor Cabang Jombang. JMD: Jurnal Riset Manajemen \& Bisnis Dewantara, 1(1), 37-48.

Ferryansyah, M. F., (2013). PENGARUH BUDAYA ORGANISASI DAN KOMITMEN ORGANISASI TERHADAP KINERJA KARYAWAN ( Studi kasus pada PPPA DARUL QUR'AN ) ( Universitas Islam Negeri Syarif Hidayatullah Jakarta ).

Ghozali, Imam. (2013). Aplikasi Analisis Multivariate dengan program IBM SPSS 21. Edisi

7. Semarang: Universitas Diponegoro.

Hasibuan, Malayu SP, (2010). Manajemen Sumber Daya Manusia. Edisi Revisi Cetakan Ke -

12. Jakarta, Penerbit : Sinar Grafika Offset

http://infobanknews.com/category/kumpulan-berita-bank-hari-ini/

Kneiter, Robert, Angelo Kinicki,. (2005). Perilaku Organisasi 2, Edisi 5. Jakarta : Salemba Empat.

Maabuat, S. E. (2016). Pengaruh Kepemimpinan, Orientasi Kerja, Dan Budaya Organisasi Terhadap Kinerja Pegawai (Studi Pada Dispenda Sulut UPTD Tondang. Jurnal Berkala Ilmiah Efisiensi. Vol 16 No. 1. Hlm 219-231.

Mangkunegara, A.P. (2006). Evaluasi Kinerja Sumber Daya Manusia. Jakarta : Refika Aditama.

Marsoit, P. Sendow, G. Rumokow. (2017). Pengaruh Pelatihan, Displin Kerja Dan Komitmen Organisasi Terhadap Kinerja Karyawan PT. Asuransi Jasa Indonesia. Jurnal EMBA. Vol 5. No. 3. Hlm. 4285-4294.

Mathis, Robert, L. dan Jackson, John H. (2009). Human Resource Management Edisi ke 10, Jakarta : Salemba Empat.

Mekta, Q. H \& Siswanto (2017). Pengaruh Kepuasan Kerja Dan Komitmen Organisasi Terhadap Kinerja Karyawan PT. Indra Kelana Yogyakarta. Jurnal Profita Edisi 2.

Mutiarni, R., \& Hidayati, N. (2018). Pengaruh Kepuasan Kerja Dan Komitmen Organisasi Terhadap Organizational Citizenship Behavior (OCB) Di Kantor Kecamatan Wilayah 
Utara Brantas, Kabupaten Jombang. JMD: Jurnal Riset Manajemen \& Bisnis Dewantara, 1(1), 25-36.

Pratiwi, Putri. (2012). Pengaruh Budaya Organisasi dan Pemberdayaan terhadap Komitmen Organisasional dalam Meningkatkan Kinerja. Jurnal Ekonomi. Vol. 14 No.1 Hal $41-52$.

Putra, S. W. (2015). “ Pengaruh Komitmen Organisasi, Budaya Organisasi, Gaya Kepemimpinan dan Lingkungan terhadap Kinerja Karyawan pada Industri Kecil ". Jurnal Ekonomi Modernisasi, 11(1), 62-77.

Robbins, Stephen P. (2006). Perilaku Organisasi. Jakarta: PT. Indeks, Kelompok Gramedia.

Robbins, Stephen P. dan Judge, Timothy A. (2008). Perilaku organisasi Edisi ke - 12, Jakarta: Salemba Empat.

Sasono, Eko. (2004). “ Mengelola Stress Kerja, Jurnal Fokus Ekonomi “. Vol III No. 2 hal 48 $-56$.

Sriekaningsih, A. (2017). Pengaruh Kepemimpinan, Budaya Organisasi, Dan Lingkungan Kerja Serta Kepuasan Kerja Terhadap Kinerja Pegawai Wilayah Kecamatan Kota Tarakan. Jurnal Borneo Administrator. Vol 13. No. 1. Hlm.57-71.

Sugiyono. (2013). Metode Penelitian Bisnis. CV Alfabeta, Bandung

Sutrisno, H. E ( 2017 ). Pengaruh Budaya Organisasi, Stress Kerja dan Komitmen Terhadap Kinerja Karyawan CV. Bintang Karya Putra di Surabaya. EKUITAS ( Jurnal Ekonomi dan Keuangan ), 14 (4), 460-477

Tika, Pabundu. (2010). Budaya Organisasi dan Peningkatan Kinerja Perusahaan. Jakarta: PT Bumi Aksara .

Wirawan. (2007). Budaya dan Iklim Organisasi. Jakarta : Salemba Empat. 